\title{
Changes in Agricultural Markets in Poland \\ following its Accession to the European Union
}

Prof. Andrzej Czyżewski Poznan University of Economics Head of Department of Macro and Agricultural Economics

Dariusz Czakowski, Ph. D. Kujawy and Pomorze University in Bydgoszcz

\section{Introduction}

Polish accession to the group of EU states changed the conditions of management and functioning of most market players and required national farms to operate in the single European market and be subject to the common agricultural policy (Jóźwiak, Michna and Mirkowska 2011, pp. 7-8). The preparation for accession in Poland commenced even before 2004. Gradual adaptation of the national structures to the EU ones was achieved, inter alia, through the support of the agricultural sector under the SAPARD programme. After the accession, in turn, the most important adjustments definitely included the removal of trade barriers, introduction of new customs tariffs and harmonized principles for the regulation of markets between Poland and EU states as well as the growth of subsidies addressed to this sector. Due to the fact that farming is accounted to the real economy, changes in institutional and economic settings and considerable financial support should determine its permanent structural transformations (Poczta 2009, pp. 9-10). However, owing to the peculiar dissimilarity of this sector from other branches of national 
economy, mainly determined by the obligation of food consumption and the specific character of the key production factor in farming, which is land, the adaptation processes in the agricultural sector were hampered (Czyżewski and Matuszczak 2011, pp. 14-16).

The consequences of this integration can be now observed in all sectors of national economy. The question therefore arises about the impact of the process on Poland's farming condition. Owing to exceptional importance of this issue, numerous reflections on the problems concerned are reported in the literature of this subject including publications of the following authors: W. Poczta, W. Czubak and K. Pawlak (2009), H. Runowski (2014), S. Kowalczyk and R. Sobiecki (2011), J. S. Zegar (2008), A. Czyżewski and A. Henisz-Matuszczak (2004), W. Jóźwiak (2012), J. Wilkin (2009). The authors of this article intended to complete the relevant literature with a new paper elaborating on the development of the market situation in the agricultural sector from the perspective of the decade preceding and following Poland's accession. Hence, the main purpose of the article was an attempt to define the most essential tendencies and transformations observed in the key markets of agricultural products in Poland which occurred during the period preceding Poland's accession to the European Union (1994-2003) and after the accession (2004-2013).

\section{Research Methodology}

The development of domestic production, consumption and real purchasing prices before and after Poland's accession to the EU were analysed and compared in order to achieve the publication's main objective. The study was preceded by the characterisation of macroeconomic and resource conditionalities of agricultural production as well as the trade balance of the Polish agri-food sector. It is worth noting that the selection criteria regarding agricultural markets comprised the largest value of their global production. On this basis, six markets of plant production (cereals, rapeseed, potatoes, sugar beet, fruit and vegetables) and five markets of livestock production (pork, beef, poultry, cows' milks and eggs) were selected for the purpose of the study. A relatively long-time horizon of the analysed period provided opportunities to build reliable statistical models. Besides, an additional reason for choosing the year 1994 as the onset of the considered period was the fact that the beginning of the '90s in Poland was marked by the extreme volatility of economy and rapid changes mainly associated to the impact of the system transformations, which could significantly distort the research findings. It is also clear that the adopted time frame could 
not eliminate this process, but only reduce it. The end of the period covered by the research, the year 2013, coincided with the EU financial perspective finishing in the same year and occurred before imposing embargo on Polish agri-food products by Russia in 2014, which could also make it difficult to attempt to assess the effects of accession for domestic supply-demand relations.

The data used in this study was drawn from the Institute of Agricultural and Food Economics - the National Research Institute and the Central Statistical Office. To achieve the research objective pursued, the authors applied, inter alia, dynamic indices that were used for comparison of the analysed phenomena in time, and average annual values of particular parameters, calculated by means of the arithmetic mean. Only the average annual indices of purchase prices of vegetables and fruit were calculated using the weighted average with the share in the final price was counted on the basis of the share in the volume of collection of each type of fruit and vegetables. All purchasing prices were additionally presented in real prices, after correction of nominal prices considering the consumer price index (CPI). 2013 was assigned as the base year to express prices.

\section{Macroeconomic and resource conditionalities and trade in the agri-food industry in Poland}

Based on the global trend for developing countries, in Poland in the years 19942013, a gradual decline was observed in the share of the agricultural sector in value added generation in the sectors of the national economy.

This was evidenced by the average annual share of farming in global production as well as in GDP generation which was determined by a slower rate of changes in agricultural product prices than the dynamics of prices in the whole economy. Unfortunately, the percentage of people employed in farming remained at relatively high levels, making it difficult to conduct structural transformations in this sector. The share of agriculture in investment expenses in national economy seen after 2004, mainly determined by Poland's accession to the European Union and, consequently, a significant increase in the funding of this sector as a result of being subject to the common agricultural policy. Poland's GDP growth during the whole analysed period was at a higher level than the average rate reported in the EU or in the world. Economic growth positively influenced larger consumption of agricultural products and created jobs in national economy. Sadly enough, the unemployment rate recorded in Poland during the period concerned oscillated between 9-20\%. In accordance with Okun's law, the development of the rate was cyclical owing to economic

Changes in Agricultural Markets in Poland following its Accession to the European 
fluctuations. Interestingly enough, in the post-accession period (2004-2013), the price indices of agricultural commodity production and the agricultural price scissors, the values of which were higher, developed in a manner more beneficial to farms than before accession (1994-2003). The above-mentioned changes were decisive in improving farms' revenues in relation to households in general.

Throughout the entire period under consideration, Poland's agricultural area steadily decreased (Table 1). In 1994, agricultural area accounted for $60 \%$ of Poland's total area, whereas in 2013 it was less than $47 \%$ of the Polish territory. This was mainly due to the exclusion of agricultural land for various non-agricultural purposes connected with the growing demand for land in other economic sectors. The above objectives first of all include the use of agricultural land for housing and economic buildings, the development of technical structure, water reservoirs, forestation and stocks of trees (Dzun 2012, pp. 19-23). A decrease in agricultural area was also caused by the limitation of agricultural activities due to economic reasons, on less fertile land (Zegar 2015, p. 150).

Changes in the agrarian structure in Poland during the analysed period suggested there was a gradual concentration and specialization of manufacturing. This was also evidenced by a decrease in the number of holdings engaged in agricultural activity and the growth of their average size and stocking density. The growth of manufacturing concentration and specialisation was also accompanied by decline in the share of small holdings in market structures as well as an increase in the share of agricultural land and stocking density in the groups of the largest holdings. However, despite the above-mentioned trend, the number of farms in Poland at the end of the period concerned was still large. Fragmentation of the agricultural structure was seen especially when compared to EU states that were leaders in the concentration and specialisation of agricultural production, such as Denmark, France or Germany. A significant number of individual farms in Poland was connected with quite a large number of people employed in agriculture, amounting to more than 2 million people on average during the post-accession period (table 1).

It is also worth mentioning that in the post-accession period there was a growth of real investments (table 1), which did not guarantee to regenerate the value of fixed assets in agriculture, but contributed to the change in their structure. The share of buildings and structures (passive equity) decreased while machines, technical devices, tools and means of transport increased. Depreciation of assets was accompanied by the ageing process of fixed assets. Their use in agriculture dynamically increased during the pre-accession period, yet, by the end of the post-accession period a relative stability was observed. During the post- 
accession period the average consumption of NPK mineral fertilisers per 1ha agricultural area was higher by $39 \%$ than in the pre-accession period. At the same time, the scale of applied calcium fertilisers significantly decreased (in the 2004-2013 period the figure was lower by 55\% than in 1994-2003). This situation appeared to be alarming from the agrotechnical point of view as it could lead to soil acidification and worse effectiveness of NPK fertilisers.

Table 1. Changes in the resources

of agricultural production factors in Poland (1994-2013)

\begin{tabular}{|c|c|c|c|c|c|c|c|c|}
\hline Item & $\begin{array}{l}\text { Total } \\
\text { agricul- } \\
\text { tural } \\
\text { area }\end{array}$ & $\begin{array}{c}\begin{array}{c}\text { Number } \\
\text { of full- } \\
\text { time } \\
\text { workers } \\
\text { (AWU) }\end{array}\end{array}$ & $\begin{array}{c}\text { Value } \\
\text { of } \\
\text { invest- } \\
\text { ment } \\
\text { (PLN/ } \\
\text { ha) }{ }^{b}\end{array}$ & $\begin{array}{c}\text { Value } \\
\text { of gross } \\
\text { fixed as- } \\
\text { sets } \\
\text { (w PLN/ } \\
\text { ha) })^{b}\end{array}$ & \begin{tabular}{|c} 
Ration \\
of fixed \\
assets \\
$(\%)$
\end{tabular} & $\begin{array}{c}\text { Average } \\
\text { number } \\
\text { of tractors } \\
\text { per } 100 \text { ha } \\
\text { agricul- } \\
\text { tural area }\end{array}$ & $\begin{array}{l}\text { Consump- } \\
\text { tion of } \\
\text { NPK } \\
\text { fertilisers } \\
\text { (kg per } \\
1 \text { ha agri } \\
\text { cultural } \\
\text { area) }\end{array}$ & $\begin{array}{c}\text { Consump } \\
\text { tion of } \\
\text { calcium } \\
\text { fertilisers } \\
\text { (kg per } \\
1 \text { ha agri } \\
\text { cultural } \\
\text { area) }\end{array}$ \\
\hline $\begin{array}{l}\text { (1)1994- } \\
2003^{\mathrm{d}}\end{array}$ & 18095 & 2683 & 208 & 14675 & 63.2 & 7.3 & 86.4 & 111.3 \\
\hline $\begin{array}{c}\text { (2)2004- } \\
2013^{\mathrm{d}}\end{array}$ & 15621 & 2136 & 283 & 10866 & 74.7 & 9.4 & 120.4 & 50.3 \\
\hline$(2) /(1)^{e}$ & $86.33 \%$ & $79.6 \%$ & $135.7 \%$ & $74 \%$ & $118.2 \%$ & $128.5 \%$ & $139.4 \%$ & $45.2 \%$ \\
\hline
\end{tabular}

a AWU - represents full-time work in agriculture. Since 2011, 1 AWU = 2120 hours of work per year. By 2010, 1 AWU was equivalent to 2200 hours of work per year. ${ }^{b}$ data for both agriculture and hunting. The amounts are expressed as constant 2013 prices - adjusted by the CPI inflation index; ${ }^{c}$ nitrogen, phosphatic and potassium fertilisers; ${ }^{d}$ arithmetic mean in years; ${ }^{e}$ index of dynamics between arithmetic means regarding the periods concerned.

Source: (GUS, 1994-2013)

The abolition of trade restrictions with the European Community countries following Poland's accession to the European union provided a good opportunity to revive domestic production by increasing the value of exports, especially that average labour cost in Poland was lower than in EU states. This situation contributed to enhancing the balance of trade in the post-accession period (2004-2013). The development of domestic economy was also confirmed by Poland's promotion in the international competitiveness ranking as well as the positive development of the import coverage ratio by export (TC) in

Changes in Agricultural Markets in Poland following its Accession to the European 
the post-accession period. It should be mentioned that in most of the analysed period, the indices regarding terms of trade and a real effective exchange rate were characterized by high volatility making it difficult to identify their explicit tendency. Nevertheless, comparing the values of both parameters makes it possible to indicate that these parameters developed more favourably in the post-accession period (average annual value of the-terms-of-trade index was higher than during the pre-accession period, whereas the real effective exchange rate was lower).

Considering the negative balance of trade in Poland in the years 1994-2013, it should be noted that the balance of trade in agri-food products following accession had positive values in each of ten years observed. However, before the accession the figures were reported to be negative nine times and only once positive in 2003. It is also worth adding that during the pre-accession period, the growth rate for imports and exports of agri-food products expressed in constant 2013 prices was relatively small. After the accession, though, a considerable growth of both indices was observed influencing a significant increase in trade. Between 1994-2003, average exports of agri-food products amounted to less than 18 billion PLN a year, whereas in 2004-2013 it was nearly 54 billion PLN. Less rapid dynamics was observed in case of changes in imports between the periods considered. The value of imports was less than 21 billion PLN a year on average during the decade preceding accession. However, in the post-accession period the average increased to more than 42 billion PLN. This observation suggests more dynamic increase in exports of agri-food products in relation to their imports. The same conclusions can be reached on the basis of the analysis of exports and imports of agri-food products in general trade. These observations suggest an increase in competitiveness of the national agrifood sector.

\section{Domestic production and consumption and purchasing prices of basic agricultural products in Poland}

The above mentioned conditionalities, most of them being favourable, contributed to an increase in the average real value of global farming production in the post-accession period by $4.9 \%$ in comparison with the preaccession period and to reversing the downward trend in global production calculated per 1ha of agricultural land. It is noteworthy that between 1998 and 2013, Poland's share of global EU agricultural production increased (from $4.4 \%$ to $5.9 \%$ ). During the post-accession period (2004-2013), in turn, 
an increase in global production value was bigger than an increase in the intermediate consumption value. This suggested an improvement of effectiveness of investments in the farming sector measured by gross value added.

Certain natural differences could be seen in the structure of the domestic agricultural production value between the share of plant and livestock production values. First of all, almost throughout the entire analysed period, plant production slightly dominated in the global production value. Yet, its share in the final and commodity production was visibly smaller than the share of livestock production, hence, its level of market output was much lower than in case of livestock production. Among the markets studied, the largest average annual share in global plant production in the post-accession period was reported respectively in: cereals, vegetables, fruit, potatoes, rapeseed and sugar beet. In turn, the essential value of global livestock production value was generated respectively by: milk, pork, poultry, eggs and beef.

The most important trends connected with the development of plant production results in the period between 1994 and 2013 in Poland included a drop in acreage and in the quantity of potatoes as well as an increase in significance of rapeseed production (Table 2). It should be also added that the real value of global potatoes production already in the pre-accession period was only lower than the global cereal production value. However, during the post-accession period, this real value was also outweighed by the values of vegetables and fruit production. In contrast, wheat cultivation definitely dominated in the structure of grain sowing and harvest. A decline in the rye cultivation area and yields was reported, which resulted from a displacement of this species by triticale characterized by the higher yield ability. Besides, the largest growth of the area sown and production output was observed during the post-accession period was noticed in the case of corn crop. Yet, the key process in the development of the shares of individual markets in Poland's livestock production generation in the period under consideration was a significant decrease in pig population and production as well as the growing importance of poultry production. A drop in the scale of pork production with a simultaneous increase in the value of cows' milk produced led to a situation where the biggest share in the structure of the production of animal products in 2004-2013 did not belong to pork production like in the pre-accession period, but only to milk production (Czakowska, Czakowski 2017, p. 234). 
Table 2. Size of domestic production and consumption and purchasing prices of basic plant and animal products in Poland in the pre-accession period (1994-2003) and post-accession (2004-2013)

\begin{tabular}{|c|c|c|c|c|c|c|c|c|c|c|c|}
\hline Item & $\begin{array}{c}\text { Cereals } \\
\text { (thous. } \\
\text { tons) }\end{array}$ & \begin{tabular}{|c} 
Rape- \\
seed \\
(thous. \\
tons)
\end{tabular} & $\begin{array}{c}\text { Potatoes } \\
\text { (thous. } \\
\text { tons) }\end{array}$ & $\begin{array}{c}\text { Sugar } \\
\text { beet } \\
\text { (thous. } \\
\text { tons) }\end{array}$ & $\begin{array}{c}\text { Fruits } \\
\text { (thous. } \\
\text { tons) }\end{array}$ & $\begin{array}{c}\text { Vege- } \\
\text { tables } \\
\text { (thous. } \\
\text { tons) }\end{array}$ & $\begin{array}{c}\text { Beef } \\
\text { (thous. } \\
\text { tons) }\end{array}$ & $\begin{array}{c}\text { Pork } \\
\text { (thous. } \\
\text { tons) }\end{array}$ & $\begin{array}{c}\text { Poultry } \\
\text { (thous. } \\
\text { tons) }\end{array}$ & $\begin{array}{c}\text { Mleka } \\
\text { krowie } \\
(\mathrm{mln} \text { l) }\end{array}$ & $\begin{array}{l}\text { Eggs } \\
\text { (thous. } \\
\text { tons) }\end{array}$ \\
\hline \multicolumn{12}{|c|}{ Domestic production } \\
\hline $\begin{array}{c}\text { (1)1994- } \\
2003^{b}\end{array}$ & 25034 & 918 & 21468 & 13612 & 2679 & 5311 & 377,4 & 2006 & 588,1 & 11659 & 420 \\
\hline $\begin{array}{l}\text { (2)2004- } \\
2013^{\mathrm{b}}\end{array}$ & 27291 & 2010 & 9945 & 11351 & 3292 & 5355 & 400,3 & 1967 & 1337 & 11919 & 570 \\
\hline$(2) /(1)^{c}$ & $109 \%$ & $219 \%$ & $46,3 \%$ & $83,4 \%$ & $122,9 \%$ & $100,8 \%$ & $106,1 \%$ & $98,1 \%$ & $227,3 \%$ & $102,2 \%$ & $135,7 \%$ \\
\hline \multicolumn{12}{|c|}{ Domestic consumption } \\
\hline $\begin{array}{c}\text { (1)1994- } \\
2003^{b}\end{array}$ & 26535 & 860 & 21418 & 13612 & 2763 & 5228 & 364 & 1914 & 581 & 11019 & 419 \\
\hline $\begin{array}{c}\text { (2)2004- } \\
2013^{\mathrm{b}}\end{array}$ & 26976 & 1907 & 10056 & 11359 & 3390 & 4901 & 198 & 1968 & 1004 & 9983 & 449 \\
\hline$(2) /(1)^{c}$ & $101,7 \%$ & $221,7 \%$ & $47,0 \%$ & $83,4 \%$ & $122,7 \%$ & $93,7 \%$ & $54,4 \%$ & $102,8 \%$ & $172,8 \%$ & $90,6 \%$ & $107,2 \%$ \\
\hline \multicolumn{12}{|c|}{ Purchasing prices ${ }^{\mathrm{d}}$} \\
\hline Item & $\begin{array}{c}\text { Cereals } \\
\text { (PLN/ } \\
\text { dt) }\end{array}$ & $\begin{array}{l}\text { Rapese- } \\
\text { ed (PLN } \\
\text { / dt) }\end{array}$ & $\begin{array}{c}\text { Potatoes } \\
\text { (PLN/ } \\
\text { dt) }\end{array}$ & $\begin{array}{c}\text { Sugar } \\
\text { beet } \\
\text { (PLN/ } \\
\text { dt) }\end{array}$ & $\begin{array}{c}\text { Fruits } \\
\text { (PLN/ } / \\
\text { dt) }\end{array}$ & $\begin{array}{c}\text { Vege- } \\
\text { tables } \\
\text { (PLN/ } \\
\text { dt) }\end{array}$ & \begin{tabular}{|c} 
Beef \\
cattle \\
$(\mathrm{PLN} /$ \\
$\mathrm{kg})$
\end{tabular} & $\begin{array}{c}\text { Pigme- } \\
\text { at (PLN } \\
\text { / kg) }\end{array}$ & \begin{tabular}{|c} 
Poultry \\
live- \\
stock \\
(PLN/ \\
kg)
\end{tabular} & \begin{tabular}{|c} 
Cow's \\
milk \\
(PLN \\
$/ 1)$
\end{tabular} & $\begin{array}{c}\text { Food } \\
\text { eggs } \\
\text { (PLN/ } \\
\text { pcs) }\end{array}$ \\
\hline $\begin{array}{c}\text { (1)1994- } \\
2003^{\mathrm{b}}\end{array}$ & 74,4 & 140,9 & 34,6 & 16,8 & 130,2 & 85 & 4,53 & 5,88 & 5,63 & 1,03 & 0,32 \\
\hline $\begin{array}{c}\text { (2)2004- } \\
2013^{\mathrm{b}}\end{array}$ & 66,7 & 138,5 & 36,9 & 15,6 & 117,4 & 73,8 & 5,24 & 4,83 & 4,03 & 1,19 & 0,24 \\
\hline$(2) /(1)^{c}$ & $89,6 \%$ & $98,3 \%$ & $106,5 \%$ & $92,7 \%$ & $90,2 \%$ & $86,9 \%$ & $115,7 \%$ & $82,1 \%$ & $71,6 \%$ & $115,5 \%$ & $75 \%$ \\
\hline
\end{tabular}

${ }^{a}$ Data for meat and fats in slaughter weight cooled; ${ }^{b}$ arithmetic mean in years; ${ }^{c}$ index of dynamics between arithmetic means regarding the periods concerned; ${ }^{\mathrm{d}}$ The amounts are expressed as constant 2013 prices - adjusted by the CPI inflation index 
Identifying the determinants of national demand for primary agricultural products supplemented the studies of production conditionalities. The main destination of agricultural raw materials is their consumption, hence, the preferences regarding food expenditure were, in the first place, subjected to observations, followed by the level of consumption displayed by Polish households. It was found that despite the growing level of real disposable income in the period between 1994 and 2013, the share of financial resources for foodstuffs steadily decreased. This process can be explained by a low income elasticity index concerning food expenses, which, in accordance with Engel's law, together with a relatively improved income situation of households, resulted in reducing foodstuffs consumption. This tendency was also conditioned by an increase in households' preferences for eating out (in food service facilities) and for eating convenient food (ready for consumption).

The level of domestic demand for agricultural products did not overlap with the changes which took place in the structure of food consumption by households mainly because of using a considerable part of these products for non-food purposes (this mainly referred to plant production). Among the most significant applications of agricultural raw materials, one can mention their use for pasturing and industrial purposes (primarily in fuel and energy industry). Therefore, due to the changes in consumer preferences as well as new trends in the use of agricultural products, national demand for them was diversified depending on the market studied. Sectors which were reported to have a marked increase in domestic consumption included rapeseed and poultry markets. It is worth mentioning at this point that increased demand for rapeseed was primarily influenced by the growing use of rapeseed oil for the production of biofuels (Czyżewski, Borychowski 2017, pp. 46-50), whereas a growth of domestic demand for poultry was connected with an increase in consumption of this meat. Reasons for higher poultry consumption included competitive prices, particularly in comparison with other types of meat, and nutritional value. Markets, in which a moderate growth of the average volume of domestic demand was observed during the post-accession period against the pre-accession period, were sectors of fruit, cereals, pork and eggs. In contrast, markets of sugar beet, vegetables and milk revealed a slight drop in national consumption. The most severe decline in national demand occurred in potatoes and beef markets. In both cases, decreased national consumption resulted from the reduced consumption of these products.

In the pre-accession period (1994-2003), the national price indices of most agricultural products were not significantly interdependent with global indices or they revealed negative correlations as in the case of rapeseed and sugar beet. 
However, in the post-accession period (2004-2013) as well as during the entire analysed period (1994-2013), positive and statistically significant correlations between domestic prices and global prices were observed with regard to almost all analysed agricultural products (Czakowski 2016). The development of real purchasing prices of most agricultural products was characterised by a downward trend in the pre-accession period (1994-2003) and a reversal of this trend in the period following accession (2004-2013). The aforementioned correlation occurred in the market of cereals, rapeseed, potatoes, vegetables, beef, pork, poultry and eggs. In the remaining three markets, with regard to the development of purchasing prices no similar relationships were found owing to high volatility of production volume (fruits) or due to numerous regulatory instruments distorting market mechanisms (sugar beet and cows' milk). Besides, average real purchasing prices of most primary agricultural products in the post-accession period were lower than in the pre-accession one (table 2). Higher average prices in the post-accession period were reported only in three markets (potatoes, beef cattle and cows' milk). Therefore, it can be concluded that in all markets of agricultural products, in which average real purchasing prices were higher in the post-accession period, there was also observed a decrease in national demand in this period. Only in the markets of sugar beet and vegetables, national demand and real purchase prices decreased at the same time. However, a decrease in average real purchasing prices and an increase in national demand were reported in case of all other agricultural products in the post-accession period.

\section{Conclusion}

Taking the observations and research into consideration, the analysed markets of agricultural products can be classified into three groups for which the situation in the studied periods developed in a similar way. The first group included markets in which the supply-demand relations developed evenly and in a favourable way. This group consisted of cereals, rapeseed, poultry and fruit. The feature they shared was a simultaneous growth of domestic production and consumption in the post-accession period. What is more, these markets were characterized by increasing international competitiveness, hence, the trade balance observed there systematically improved. A twofold increase in (national and foreign) demand led to a situation where the production level in these markets systematically grew, even despite no apparent increase in prices in the post-accession period. 
The second group included markets which were highly competitive in the international scale and their production growth primarily relied on the dynamic export development in the post-accession period. This group involved markets of cows' milk, beef and vegetables. Yet, the development of supply-demand relations observed in these markets was shaken by a visible decline in domestic demand.

Finally, the third group of markets included potatoes, sugar beet and pork. These were the only markets of the ones analysed in which the domestic production level was lower in the period following accession than before it. It is also noteworthy that a reduction in potatoes consumption was caused by a drop in their use as well as their exploitation in processing and industry, whereas a decrease in pork production volume was mainly determined by this sector's low international competitiveness which, in turn, resulted in a clearly higher import in this market. A reduction of sugar beet harvest could be partially affected by numerous regulations implemented in this market in the post-accession period.

Nevertheless, despite the prevailing scale of Poland's trade with EU countries, it should be noted that the observed changes in agricultural markets were also determined by processes taking place in the global environment, particularly in the area of production and consumption of agricultural products. These include, among others, the increase in population and the improvement of its income situation in developing countries, the change in global consumption patterns, the increase in industrial demand for cereals and vegetable oil, the speculative activities and the transmission of energy prices to agricultural products.

\section{Summary}

\section{Changes in Agricultural Markets in Poland following its Accession to the European Union}

This article attempts to determine the most significant tendencies and changes observed in Poland's core markets of agricultural products, which occurred during the period preceding Poland's accession to the European Union (1994-2003) and after the accession (2004-2013). The key markets of agricultural products include markets with the largest value of commodity production during the analysed period, such as cereals, potatoes, sugar beet, rapeseed, fruit, vegetables, pork, beef and poultry, cows' milks and eggs. The development of domestic production, consumption and real purchasing prices were observed and compared in order to achieve the main objective. The research was preceded by the characterisation of macroeconomic and resource conditionalities of agricultural production as well as 
the trade balance of the Polish agri-food sector. On the basis of the conducted studies, there were singled out three groups of markets in which the situation during the period following Poland's accession to the EU developed in a similar way.

Key words: agricultural markets, European integration.

\section{Streszczenie}

\section{Zmiany na rynkach rolnych $w$ Polsce po akcesji do Unii Europejskiej}

$\mathrm{W}$ artykule podjęto próbę określenia najistotniejszych tendencji i zmian zaobserwowanych na podstawowych rynkach produktów rolnych w Polsce, którenastąpiły w okresie przed akcesją Polskido Unii Europejskiej (1994-2003) oraz po niej (2004-2013). Do podstawowych rynków produktów rolnych zaliczono rynki charakteryzujące się największą wartością produkcji towarowej $\mathrm{w}$ badanym okresie, takie jak: zboża, ziemniaki, buraki cukrowe, rzepak, owoce, warzywa, mięso wieprzowe, wołowe i drobiowe, mleko krowie i jaja. Realizacji celu głównego posłużyła obserwacja i porównanie kształtowania się krajowej produkcji i zużycia oraz realnych cen skupu. Badania poprzedzono scharakteryzowaniem uwarunkowań makroekonomicznych i zasobowych produkcji rolnej oraz bilansu wymiany handlowej polskiego sektora rolno-spożywczego. Na podstawie przeprowadzonych badań wyodrębniono trzy grupy rynków, na których sytuacja w okresie po akcesji Polski do Unii Europejskiej kształtowała się w zbliżony sposób.

\section{Słowa}

kluczowe: rynki rolne, integracja europejska.

JEL

Classification: Q11, Q13

\section{References}

1. Czakowski D. (2016), Tendencje w kształtowaniu się cen skupu podstawowych produktów roślinnych przed i po akcesji Polski do Unii Europejskiej (1994-2013), Roczniki Ekonomicze Kujawsko-Pomorskiej Szkoły Wyższej Bydgoszczy, No. 9, p. 247-260. 
2. Czakowska H., Czakowski D. (2017), Podaż mleka w województwie KujawskoPomorskim na tle sytuacji ogólnokrajowej po akcesji do UE [in:] Czyżewski A., Matuszczak A. (ed.), Ocena i przyszłość wspólnej polityki rolnej po 2020 roku, KPSW, Bruksela-Bydgoszcz-Poznań.

3. Czyżewski A., Henisz-Matuszczak A. (2004), Rolnictwo Unii Europejskiej i Polski. Studium porównawcze struktur wytwórczych i regulatorów rynków rolnych, Publishing House of Poznan University of Economics, Poznan.

4. Czyżewski A., Matuszczak A. (2011), Dylematy kwestii agrarnej w panoramie dziejów, Zeszyty Naukowe Szkoły Głównej Gospodarstwa Wiejskiego, Ekonomika i Organizacja Gospodarki Żywnościowej, No. 90, p. 5-23.

5. Czyżewski B., Borychowski M. (2017), Rozwój sektora biopaliw ciektych $w$ Polsce i Niemczech, PWN, Warszawa.

6. Dzun W. (2012), Zmiany skali wykorzystania zasobów gruntów rolnych w Polsce $w$ procesie przemian systemowych $i$ integracji z Unia Europejska, Zagadnienia Ekonomiki Rolnej, No. 1, p. 18-39.

7. Józwiak W. (2012), Polskie rolnictwo i gospodarstwa rolne w pierwszej i drugiej dekadzie XXI wieku, Program Wieloletni 2011-2014 (No. 52), IERiGŻ-PIB, Warszawa.

8. Jóźwiak W., Michna W., Mirkowska Z. (2011), Procesy zachodzace $w$ rolnictwie polskim $w$ latach 1990-2010, projekcje na rok 2013 i pożądana wizja rolnictwa w 2020 roku - zagadnienia wybrane, Program Wieloletni 2011-2014 (No. 21), IERiGŻ-PIB, Warszawa.

9. Kowalczyk S., Sobiecki R. (2011), Europejski model rolnictwa-uwarunkowania ewolucji, Roczniki Nauk Rolniczych, series G, Vol. 98, Issue 3, p. 9-20.

10. Poczta W. (2009), Wptyw integracji z UE na sytuacje strukturalna, produkcyjna i ekonomiczna polskiego rolnictwa, [in:] Urban, R. (re.), Stan polskiej gospodarki żywnościowej po przystapieniu do Unii Europejskiej, Program Wieloletni 2005-2009 (No. 145), IERiGŻ-PIB, Warszawa.

11. Poczta W., Czubak, W., Pawlak K. (2009), Zmiany w woluminie produkcji $i$ dochodach rolniczych $w$ warunkach akcesji Polski do UE, Zagadnienia ekonomiki rolnej, No. 4, p. 40-52.

12. Rocznik Statystyczny (1994-2013), GUS, Warszawa.

13. Runowski H. (2014), Ekonomika rolnictwa - przemiany w gospodarstwach rolnych, w: Rolnictwo, gospodarka żywnościowa, obszary wiejskie - 10 lat w Unii Europejskiej, SGGW, Warszawa, p. 31-48.

14. Wilkin J. (2009), Uwarunkowania rozwoju polskiego rolnictwa w kontekście europejskim i globalnym. Implikacje teoretyczne i praktyczne. [in:] Płowiec, U. (ed.), Polityka gospodarcza a rozwój kraju, PTE, Warszawa.

15. Zegar J. S. (2008), Dochody w rolnictwie w okresie transformacji i integracji europejskiej, IERiGŻ-PIB, Warszawa

16. Zegar J. S. (2015), Polskie rolnictwo w okresie dwóch przełomów - transformacji ustrojowej i integracji europejskiej, Nierówności społeczne a wzrost gospodarczy, (No. 41), p. 148-160. 